The Free Internet Journal for Organic Chemistry
Paper

Arkivoc 2019, part v, 0-0

to be inserted by editorial office

\title{
Stereoselective synthesis of marine macrolide Aspergillide D
}

\author{
Anil Talakokkula, Karunakar Baikadi, and A. Venkat Narsaiah* \\ Organic Synthesis Laboratory, Fluoro-Agrochemicals Department, \\ CSIR-Indian Institute of Chemical Technology, Hyderabad, Telangana, India
}

Email:vnakkirala2001@yahoo.com; vnakkirala@csiriict.in

Received 03-25-2019

Accepted 05-30-2019

Published on line 06-07-2019

\section{Abstract}

A formal stereoselective synthesis of the naturally occurring 16-membered macrolide aspergillide $D$ is described. The origins of the chiral centers are ribose, lactic acid and the Sharpless asymmetric epoxidation protocol. The foremost reactions involved are Yadav's protocol, the Ohira- Bestmann reaction and alkyl-iodide coupling.

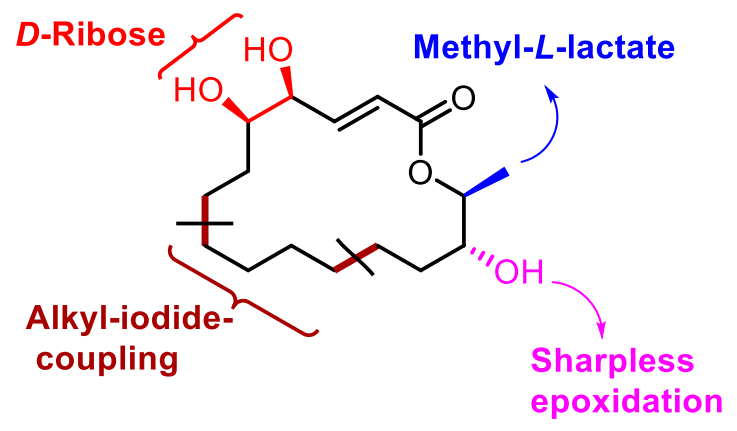

Aspergillide D

Keywords: Aspergillide D, D-ribose, methyl L-lactate, epoxidation, coupling, macrolide 


\section{Introduction}

Aspergillus is a genus consisting of hundreds of species of fungi found in various climates and causes aspergillosis diseases. They also produce secondary metabolites like aspergillides, aspergillic acid along with many other compounds. Aspergillides A-C are 14-membered macrolides, incorporating a trans-tetra hydropyran ring and aspergillic acid, which is a substituted pyrazine. ${ }^{1,2}$ Aspergillide $D$ is a 16-membered macrolide, isolated from the extract of a gorgonian associated marine fungal strain Aspergillus sp.SCSGAF0076. The structural confirmation by ${ }^{1} \mathrm{H},{ }^{13} \mathrm{C}$ NMR, NOESY, HRMS-ESI and DEPT spectral analysis was performed by the Qi group. ${ }^{3}$ The first asymmetric synthesis of aspergillide $D$ was reported by Mohapatra et al. ${ }^{4}$<smiles>C[C@@H]1OC(=O)/C=C/[C@H](O)[C@@H](O)CCCCCCCC[C@H]1O</smiles>

Aspergillide-D<smiles>C[C@@H]1CCC/C=C/[C@H]2CC[C@@H](O)[C@@H](CC(=O)O1)O2</smiles>

Aspergillide-A<smiles>C[C@H]1CCC/C=C/[C@H]2CC[C@@H](O)[C@@H](CC(=O)O1)O2</smiles>

Aspergillide-B<smiles>C[C@H]1CCCC=C[C@H]2C=C[C@@H](O)[C@@H](CC(=O)O1)O2</smiles><smiles>CCC(C)c1cnc(CC(C)C)c(=O)n1O</smiles>

Aspergillide-C

Aspergillic acid

\section{Figure 1}

\section{Results and Discussion}

As part of our regular research program for the synthesis of biologically active natural products, ${ }^{5-8}$ herein we report the formal stereoselective synthesis of aspergillide D. The retrosynthetic analysis (Scheme 1) reveals that aspergillide $D$ could be synthesized by intramolecular macrolactonisation of fragment 16. The ester (16) could be derived by the coupling of alkyne (3) and iodide fragments (12). The alkyne fragment could be accomplished from $D$-ribose and the iodide intermediate from methyl $L$-lactate (4).<smiles>C=CC=CC(=O)O[C@@H](C)[C@@H](O)CCCCCCCC[C@@H](O)[C@@H](O)C=C</smiles>

Aspergillide-D

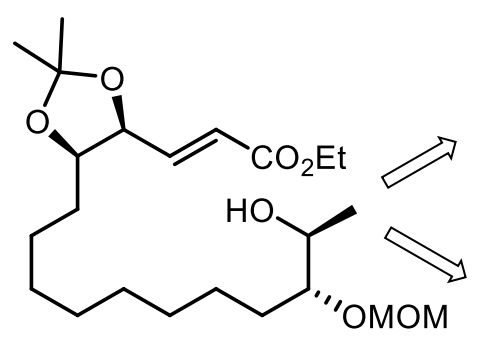

16

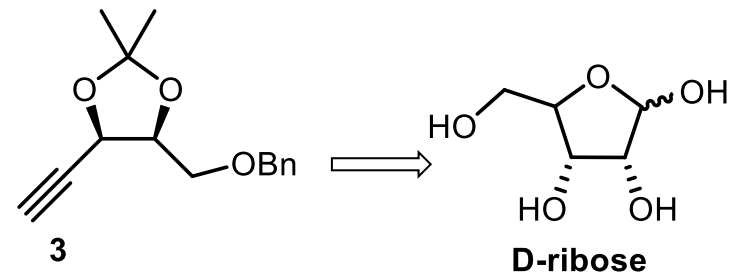<smiles>C=CC[13C](C)C(C)[C@H](C)[C@@H](CCCCCCI)OC</smiles>

12<smiles>COC(=O)[C@@H](C)O</smiles>

4

\section{Scheme 1}


As depicted in Scheme 2, the synthesis of the alkyne fragment was started from the known alcohol 1, which was prepared from commercially available $D$-ribose using well known reports. ${ }^{9-12}$ The alcohol 1 was protected as its benzyl ether ${ }^{13}$ with benzyl bromide in presence of $\mathrm{NaH}$ in THF to afford compound 2, which on further oxidative cleavage of terminal olefin via Jin's protocol by using $\mathrm{OsO}_{4}, 2,6$-lutidine, and $\mathrm{NaIO}_{4} \mathrm{leads}_{\text {to }}$ the corresponding terminal aldehyde, ${ }^{14,15}$ which was subsequentially subjected to the Ohira-Bestmann reagent ${ }^{16}$ to get the terminal alkyne fragment (3) in good yields.

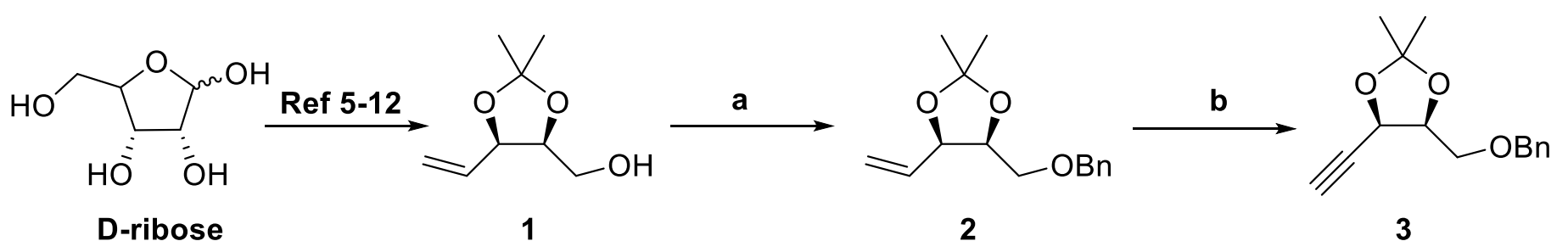

Reagents \& Conditions: (a) $\mathrm{NaH}, \mathrm{BnBr}$, THF $0{ }^{\circ} \mathrm{C}$ to rt, $16 \mathrm{~h}$; (b) (i) $\mathrm{OsO}_{4}, \mathrm{NaIO}_{4}, 2,6$-lutidine, 1,4-dioxane/ $\mathrm{H}_{2} \mathrm{O}$ (3:1), $25^{\circ} \mathrm{C}, 3 \mathrm{~h}$; (ii) Dimethyl(1-diazo-2-oxopropyl)phosphonate, $\mathrm{K}_{2} \mathrm{CO}_{3}, \mathrm{MeOH}, \mathrm{rt}$., $5 \mathrm{~h}, 68 \%$ over two steps.

\section{Scheme 2}

The synthesis of the iodide fragment 12 , was started from commercially available methyl $L$-lactate ${ }^{17}(4)$, by protection of the secondary alcohol as its silyl ether using TBDPS-Cl in the presence of base. This was followed by a controlled reduction of the ester to give the desired aldehyde, which was immediately subjected to a homologation reaction with a two carbon Wittig yilde leading to the $\alpha, 6$-unsaturated ester $\mathbf{5}$. Reduction of the ester moiety was efficiently carried out using DIBAL-H at $-78{ }^{\circ} \mathrm{C}$ in $\mathrm{CH}_{2} \mathrm{Cl}_{2}$ to afford the allylic alcohol in good yield. Thus obtained double bond was subjected to Sharpless asymmetric epoxidation ${ }^{18-20}$ using (+)-DIPT as a chiral source in presence of $\mathrm{Ti}\left(\mathrm{O}^{i}-\mathrm{Pr}\right)_{4}$ and TBHP at $-20{ }^{\circ} \mathrm{C}$ to furnish the desired epoxide 6 in good yields. Yadav's protocol 21,22 was applied here for a base induced elimination reaction to give the chiral propargyl alcohol 7 in $90 \%$ yield overall covering two steps from the epoxy alcohol (6) using $\mathrm{CCl}_{4}-\mathrm{Ph}_{3} \mathrm{P}$ under reflux conditions followed by reaction with $n$-BuLi at $-20{ }^{\circ} \mathrm{C}$ in THF. The hydroxyl functionality in propargyl alcohol 7 was protected as a methoxymethyl ether with $\mathrm{MOM}-\mathrm{Cl}$ in the presence of DIPEA to afforded compound 8 in excellent yield. ${ }^{23}$

Coupling of (5R,6S)-5-ethynyl-6,9,9-trimethyl-8,8-diphenyl-2,4,7-trioxa-8-siladecane (8) and tert-butyl-(4iodobutoxy)-dimethylsilane was carried out in the presence of $n$-BuLi 24,25 to afford compound 9 in $70 \%$ yield. The selective desilylation of TBS in the presence of TBDPS ether with pyridinium $p$-toluenesulfonate ${ }^{26}$ in methanol at room temperature afforded the primary alcohol 10. Saturation of the triple bond was achieved with $\mathrm{Pd} / \mathrm{C}^{27}(10 \%)$ under a hydrogen atmosphere in EtOAc to yield alcohol 11. The corresponding alcohol was transformed into the iodide ${ }^{28}$ in the presence of iodine-TPP at toluene-acetonitrile (3:1) under reflux conditions to afford compound 12. 

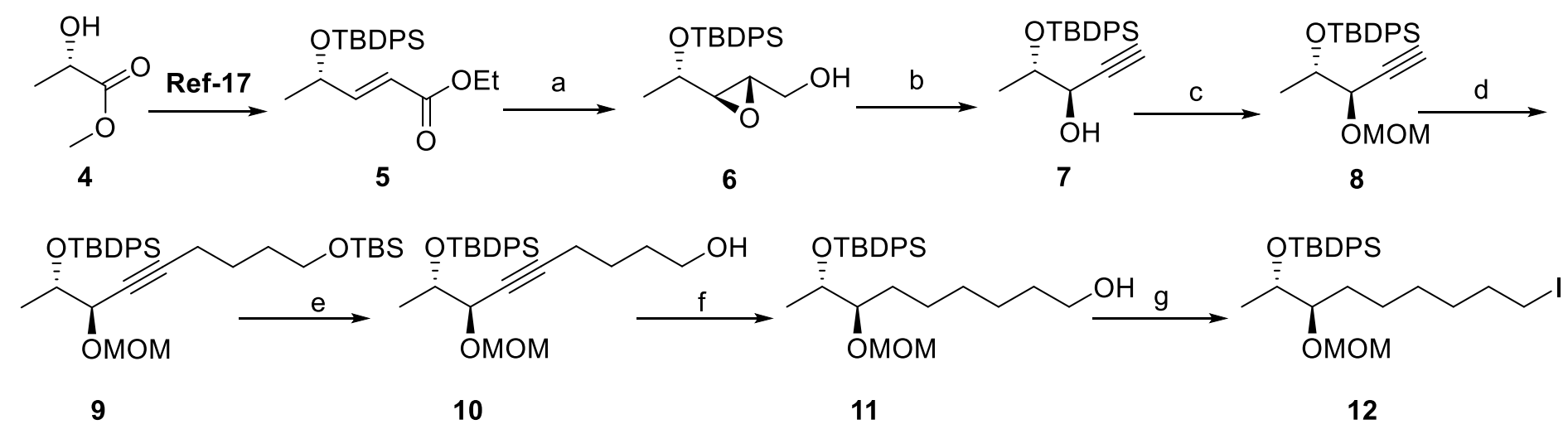

Reagents and Conditions: (a) (i) DIBAL-H, $\mathrm{CH}_{2} \mathrm{Cl}_{2},-78{ }^{\circ} \mathrm{C}, 30 \mathrm{~min}, 85 \%$; (ii) (+)-DIPT, Ti(O'Pr) 4 , TBHP, $\mathrm{CH}_{2} \mathrm{Cl}_{2},-20$ ${ }^{\circ} \mathrm{C}, 12 \mathrm{~h}, 95 \%$; (b) (i) $\mathrm{CCl}_{4}$, TPP, reflux, $5 \mathrm{~h}, 95 \%$; (ii) $n$-BuLi, $-20{ }^{\circ} \mathrm{C}, 30 \mathrm{~min}, \mathrm{THF}, 85 \%$; (c) MOMCl, DIPEA, $\mathrm{CH}_{2} \mathrm{Cl}_{2}$, rt., 12 h, 96\%; (d) tert-Butyl-(4-iodobutoxy)dimethylsilane, $n$-Buli, THF:HMPA (2:1), -78 ${ }^{\circ} \mathrm{C}, 1.5$ h, 70\%; (e) PPTS, $\mathrm{MeOH}, \mathrm{rt}, 1 \mathrm{~h}, 90 \%$; (f) H2, Pd/C (10\%), EtOH, rt, 16 h, 90\%, (g) TPP, I2, Imidazole, Toluene / Acetonitrile (3:1), rt, $30 \mathrm{~min}, 95 \%$.

\section{Scheme 3}

The coupling of iodide 12 and the alkyne compound $\mathbf{3}$ was carried out in the presence of $n-\mathrm{BuLi}^{24,25}$ in a THF-HMPA (2:1) mixture at $-78{ }^{\circ} \mathrm{C}$ to obtain the desired compound 13 in $73 \%$ yield. The concomitant removal of the triple bond as well as the benzyl group was achieved via a Pd/C (10\%) catalyzed hydrogenation in EtOAc to afford the saturated primary alcohol ${ }^{29} 14$ in $90 \%$ yield.

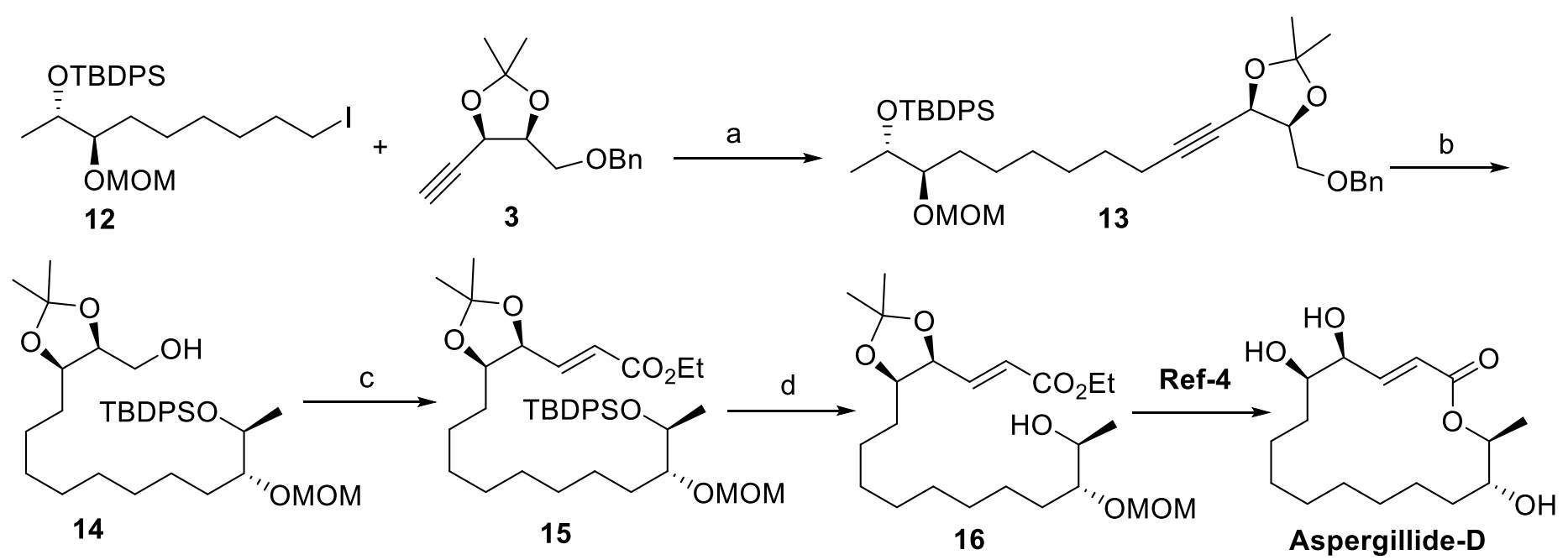

Reagents \& Conditions: (a) 3, n-BuLi, THF/HMPA (2:1), -78 ${ }^{\circ} \mathrm{C}, 90 \mathrm{~min}, 73 \%$; (b) $\mathrm{H}_{2}, \mathrm{Pd} / \mathrm{C}$, EtOH, rt, 16 h, $90 \%$; (c) (i) $\mathrm{DMP}, \mathrm{NaHCO}_{3}, \mathrm{CH}_{2} \mathrm{Cl}_{2}, \mathrm{O}^{\circ} \mathrm{C}$ to $\mathrm{rt}, 1 \mathrm{~h}$, (ii) $\mathrm{Ph}_{3} \mathrm{P}=\mathrm{CHCO}_{2} \mathrm{Et}$, toluene, reflux, $2 \mathrm{~h}, 75 \%$ over two steps; (d) $\mathrm{HF} \bullet \mathrm{Py}, \mathrm{THF}, \mathrm{O}^{\circ} \mathrm{C}$ to $\mathrm{rt}, 12 \mathrm{~h}, 75 \%$.

\section{Scheme 4}

Oxidation of the primary alcohol with Dess-martin periodinane in $\mathrm{CH}_{2} \mathrm{Cl}_{2}$ gave the corresponding aldehyde and was immediately reacted with the $\mathrm{C}_{2}$-ylide in a Wittig reaction resulting in the $\alpha, 6$ - unsaturated ester ${ }^{30}$ in 
good yield. Finally, the TBDPS group in compound $\mathbf{1 5}$ was deprotected using HF•Pyridine 31,32 in THF at room temperature to afford the secondary alcohol $\mathbf{1 6}$ in very good yield. This completed the formal synthesis of the aspergillide $\mathrm{D}$ fragment $\mathbf{1 6}$ which was identical in all aspects with the compound reported in the literature data. ${ }^{4}$

\section{Conclusions}

In summary, we have synthesized the desired intermediate 16, which completes the formal synthesis of aspergillide $D$ in an efficient and completely stereo controlled manner with the longest linear sequence of 14 steps in good yields. The synthesis was started from commercially available starting materials and the majority of the required stereo centers were deduced from natural sources such as methyl $L$-lactate and $D$-ribose. The key reactions involved in the synthesis are the Sharpless asymmetric epoxydation, Ohira-Bestmenn reagent, Yadav's protocol for propargyl alcohols and the alkyl iodide coupling.

\section{Experimental Section}

General. All the air and moisture sensitive reactions were carried out under an inert atmosphere (nitrogen or argon). Oven-dried glass ware was used to perform all the reactions. Freshly distilled anhydrous solvents were used for air and moisture sensitive reactions. Commercially available reagents were used as such. The purification of the compounds was carried out via column chromatography using silica gel (60-120 mesh) packed in glass columns. ${ }^{1} \mathrm{H} \mathrm{NMR}$ and ${ }^{13} \mathrm{C} \mathrm{NMR}$ were recorded in $\mathrm{CDCl}_{3}$ on a $400 \mathrm{MHz}$ and $500 \mathrm{MHz}$ Brucker spectrometer, using TMS as an internal standard. IR spectra were recorded on a Perkin-Elmer FT-IR 240-C spectrophotometer using $\mathrm{KBr} /$ Thin Film optics. Mass spectra were recorded on a Finnigan MAT 1020 mass spectrometer operating at $70 \mathrm{eV}$. Optical rotation values were recorded on a Horiba sepa 300 polarimeter. High resolution mass spectra (HRMS) [ESI+] were obtained using either a TOF or a double focusing spectrometer.

(4S,5R)-4-[(Benzyloxy)methyl]-2,2-dimethyl-5-vinyl-1,3-dioxolane (2). To a stirred solution of $\mathrm{NaH}(0.46 \mathrm{~g}$, $11.3 \mathrm{mmol})$ in THF $(20 \mathrm{~mL})$ was added [(4S,5R)-2,2-dimethyl-5-vinyl-1,3-dioxolan-4-yl]methanol (1.55 g, 9.5 mmol), which was dissolved in THF $(10 \mathrm{~mL}) . \mathrm{BnBr}$ was slowly added $(1.24 \mathrm{~mL}, 10.4 \mathrm{mmol})$ at $0^{\circ} \mathrm{C}$, then the reaction mixture was stirred at room temperature for $16 \mathrm{~h}$. After completion of the reaction (confirmed by TLC), the reaction mixture was diluted by adding EtOAc $(25 \mathrm{~mL})$ and was quenched with saturated $\mathrm{NaHCO}_{3}$. The reaction mixture was extracted with EtOAc $(2 \times 20 \mathrm{~mL})$ and the combined organic layers were dried over $\mathrm{Na}_{2} \mathrm{SO}_{4}$, then evaporated under reduced pressure. The crude product was purified by column chromatography using silica gel (60-120 mesh) by eluting with a EtOAc-hexane (1:9) mixture to afford, olefin 2 (1.4 g, 90\%) as an oil. Optical rotation $[\alpha]_{\mathrm{D}}{ }^{25}+5.5\left(\mathrm{c}=1, \mathrm{CHCl}_{3}\right) .{ }^{\mathrm{Lit}}[\alpha]_{\mathrm{D}}{ }^{25}+1.7\left(\mathrm{c}=1, \mathrm{CHCl}_{3}\right)^{13}$; IR (neat): 2987, 2929, 2868, 1696, 1374, 1223, 1092, 737, 772, $697 \mathrm{~cm}^{-1} ;{ }^{1} \mathrm{H}$ NMR (400 MHz, CDCl 3$): \delta 7.37-7.27(\mathrm{~m}, 5 \mathrm{H}), 5.86-5.76(\mathrm{~m}, 1 \mathrm{H}), 5.35$ (dt, 1H, J 17.1, 1.3 Hz), $5.21(\mathrm{dt}, 1 \mathrm{H}, J 10.3,0.9 \mathrm{~Hz}), 4.56-4.64(\mathrm{~m}, 2 \mathrm{H}), 4.51(\mathrm{~d}, 1 \mathrm{H}, J 12.0 \mathrm{~Hz}), 4.42-4.36(\mathrm{~m}$, $1 \mathrm{H}), 3.47(\mathrm{~d}, 1 \mathrm{H}, J 2.4 \mathrm{~Hz}), 3.45(\mathrm{~d}, 1 \mathrm{H}, J 1.3 \mathrm{~Hz}), 1.50(\mathrm{~s}, 3 \mathrm{H}), 1.39(\mathrm{~s}, 3 \mathrm{H}) ;{ }^{13} \mathrm{C} \mathrm{NMR}(100 \mathrm{MHz}, \mathrm{CDCl} 3): \delta 137.9$, 133.5, 128.3, 127.7, 127.6, 118.1, 108.8, 78.4, 76.9, 73.4, 69.4, 27.8, 27.3; HRMS (ESI): $\mathrm{m} / z$ [M + Na] ${ }^{+}$calcd for $\mathrm{C}_{15} \mathrm{H}_{20} \mathrm{NaO}_{3}: 271.1059$; found: 271.1279. 
(4S,5R)-4-[(Benzyloxy)methyl]-5-ethynyl-2,2-dimethyl-1,3-dioxolane (3). To a stirred solution of olefin 2 (1.25 $\mathrm{g}, 5.0 \mathrm{mmol})$ in a dioxane-water $(3: 1,12 \mathrm{~mL})$ mixture was added 2,6-lutidine $(1.2 \mathrm{~mL})$ and $\mathrm{OsO}_{4}(0.025 \mathrm{~g}, 0.1$ $\mathrm{mmol})$, which was dissolved in tert- $\mathrm{BuOH}$, followed by $\mathrm{NaIO}_{4}(4.3 \mathrm{~g}, 20.2 \mathrm{mmol})$ at room temperature. The resulting mixture was stirred for $12 \mathrm{~h}$. The completion of reaction was confirmed by TLC, then diluted with $\mathrm{CH}_{2} \mathrm{Cl}_{2}(15 \mathrm{~mL})$ and quenched with water $(15 \mathrm{~mL})$. The organic layer was separated and the aqueous layer was extracted with $\mathrm{CH}_{2} \mathrm{Cl}_{2}(2 \times 25 \mathrm{~mL})$. The combined organic layers were washed with a brine solution, dried over $\mathrm{Na}_{2} \mathrm{SO}_{4}$, and concentrated under vacuum. The crude product was purified by column chromatography using silica gel (60-120 mesh) by eluting with a EtOAc-hexane (5:5) mixture to afford, (4S,5S)-5-[(benzyloxy)methyl]2,2-dimethyl-1,3-dioxolane-4-carbaldehyde (1.0 g, 80\%) as a liquid.

To a stirred solution of the above aldehyde $(0.98 \mathrm{~g}, 3.9 \mathrm{mmol})$ in methanol $(15 \mathrm{~mL})$ was added dimethyl-1diazo-2-oxopropyl phosphonate $(0.9 \mathrm{~g}, 4.7 \mathrm{mmol})$ at $0{ }^{\circ} \mathrm{C}$ and then $\mathrm{K}_{2} \mathrm{CO}_{3}$ was added $(1.35 \mathrm{~g}, 9.8 \mathrm{mmol}) \mathrm{in}$ portions over 10 minutes. The reaction was allowed to stir at $0{ }^{\circ} \mathrm{C}$ for $2 \mathrm{~h}$ and then slowly warm up to r.t. and stirred for $1 \mathrm{~h}$. After the completion of the reaction (monitored by TLC), the solvent was evaporated under reduced pressure. The residue was quenched with saturated ammonium chloride and extracted with EtOAc $(2 \times 20 \mathrm{~mL})$, the organic layers were washed with brine, dried over $\mathrm{Na}_{2} \mathrm{SO}_{4}$, and evaporated under reduced pressure. Purification was performed by column chromatography using silica gel (60-120 mesh) by eluting with a EtOAc-hexane (1:9) mixture to afford alkyne $3(0.72 \mathrm{~g}, 72 \%)$ as an oil. Optical rotation $[\alpha]_{\mathrm{D}} 25+26.8(\mathrm{c}=0.5$, $\mathrm{CHCl}_{3}$ ); IR (neat): 3032, 2923, 2854, 2225, 1220, 1063, $\left.772 \mathrm{~cm}^{-1} ;{ }^{1} \mathrm{H} \mathrm{NMR} \mathrm{(400} \mathrm{MHz,} \mathrm{CDCl} 3\right): \delta 7.38-7.27$ (m, $5 \mathrm{H}), 4.83(\mathrm{dd}, 1 \mathrm{H}, J 5.8,2.2 \mathrm{~Hz}), 4.59(\mathrm{ABq}, 2 \mathrm{H}, J 24.9,12.1 \mathrm{~Hz}), 4.37-4.32(\mathrm{~m}, 1 \mathrm{H}), 3.76(\mathrm{dd}, 2 \mathrm{H}, J 6.2,2.7 \mathrm{~Hz})$, $2.49(\mathrm{~d}, 1 \mathrm{H}, J 2.2 \mathrm{~Hz}), 1.55$ (s, 3H), 1.37 (s, 3H); ${ }^{13} \mathrm{C}$ NMR $\left(100 \mathrm{MHz} \mathrm{CDCl}_{3}\right): \delta 137.8,128.4,127.9,127.7,110.6$, 79.4, 76.4, 75.5, 73.6, 69.8, 67.6, 27.6, 25.9; HRMS (ESI): $m / z$ [M + Na] $]^{+}$calcd. for $\mathrm{C}_{15} \mathrm{H}_{18} \mathrm{O}_{3}:$ : 269.11482; found: 269.11794.

Ethyl-(4S,2E)-4-[(t-butyldiphenylsilyl)oxy]pent-2-enoate (5). To a stirred solution of (S)-2-[(tert-butyldi phenylsilyl)oxy]propanal $(4.5 \mathrm{~g}, 14.4 \mathrm{mmol})$ in toluene $(50 \mathrm{~mL})$ was added $\mathrm{Ph}_{3} \mathrm{P}=\mathrm{CHCO}_{2} \mathrm{Et}(6.5 \mathrm{~g}, 18.7 \mathrm{mmol})$. The resulting mixture was refluxed for $2 \mathrm{~h}$ and the completion of reaction was confirmed by TLC, then quenched with water and extracted with EtOAc $(2 \times 30 \mathrm{~mL})$. The combined organic layers were dried over $\mathrm{Na}_{2} \mathrm{SO}_{4}$, the solvent was evaporated under reduced pressure and the crude was purified by column chromatography using silica gel (60-120 mesh) by eluting with EtOAc-hexane (1:9) mixture to afford, (4S,2E)ethyl-4-[(tert-butyldiphenylsilyl)oxy]pent-2-enoate, $5(5.1 \mathrm{~g}, 92 \%)$ as a liquid. Optical rotation $[\alpha]_{\mathrm{D}}{ }^{25}-38.0$ (c = $1, \mathrm{CHCl}_{3}$ ), ${ }^{\mathrm{Lit}}[\alpha]_{\mathrm{D}}{ }^{25}-38.0$ (c = 1, $\left.\mathrm{CHCl}_{3}\right)^{17}$; IR (neat): 2925, 2855, 1725, 772, 703, $578 \mathrm{~cm}^{-1} ;{ }^{1} \mathrm{H} \mathrm{NMR}(400 \mathrm{MHz}$, $\left.\mathrm{CDCl}_{3}\right): \delta 7.70-7.61(\mathrm{~m}, 4 \mathrm{H}), 7.46-7.33(\mathrm{~m}, 6 \mathrm{H}), 6.89(\mathrm{dd}, 1 \mathrm{H}, J=15.5,4.4 \mathrm{~Hz}), 6.00(\mathrm{dd}, 1 \mathrm{H}, J 15.5,1.6 \mathrm{~Hz})$, $4.50-4.42(\mathrm{~m}, 1 \mathrm{H}), 4.24-4.14(\mathrm{~m}, 2 \mathrm{H}), 1.30(\mathrm{t}, 3 \mathrm{H}, J 7.0 \mathrm{~Hz}), 1.13(\mathrm{~d}, 3 \mathrm{H}, J 6.6 \mathrm{~Hz}), 1.08(\mathrm{~s}, 9 \mathrm{H}) ;{ }^{13} \mathrm{C} \mathrm{NMR}(100$ $\mathrm{MHz}_{\mathrm{CDCl}}$ ): $\delta$ 166.8, 151.5, 135.8, 135.7, 133.9, 133.4, 129.7, 127.6, 127.6, 119.1, 68.6, 60.3, 26.9, 23.3, 19.2, 14.3; $\mathrm{HRMS}(\mathrm{ESI}): \mathrm{m} / z$ [M + Na] ${ }^{+}$calcd. for $\mathrm{C}_{23} \mathrm{H}_{30} \mathrm{O}_{3} \mathrm{NaSi}: 405.18564$; found: 405.18602 .

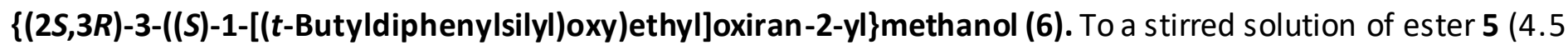
$\mathrm{g}, 11.8 \mathrm{mmol})$ in dry $\mathrm{CH}_{2} \mathrm{Cl}_{2}(60 \mathrm{~mL})$ was added DIBAL-H $(15.4 \mathrm{~mL}, 27.1 \mathrm{mmol})$ drop wise at $-78{ }^{\circ} \mathrm{C}$ and was stirred for $30 \mathrm{~min}$ at the same temperature. The reaction was then quenched with saturated Rochelle salt and stirred for a further $6 \mathrm{~h}$. The organic layer was separated and the aqueous layer was extracted with EtOAc $(3 \times 20 \mathrm{~mL})$. The combined organic layers were washed with brine $(30 \mathrm{~mL})$ and dried over $\mathrm{Na}_{2} \mathrm{SO}_{4}$. Evaporation of the solvent under reduced pressure led to a crude product that was purified by column chromatography using silica gel (60-120 mesh) by eluting with a EtOAc-hexane (2:8) mixture to afford, $(4 S, 2 E)-4-[(t e r t-$ butyldiphenylsilyl)oxy]pent-2-en-1-ol (3.4 g, 85\%) as colorless liquid. 
To a stirred solution of (+)-DIPT $(0.58 \mathrm{~mL}, 2.8 \mathrm{mmol})$ and molecular sieves $\left(2.0 \mathrm{~g}, 4{ }^{\circ} \mathrm{A}\right)$ in anhydrous $\mathrm{CH}_{2} \mathrm{Cl}_{2}$ at $20{ }^{\circ} \mathrm{C}$ were added $\mathrm{Ti}\left(\mathrm{O}^{i} \mathrm{Pr}\right)_{4}(1.13 \mathrm{~mL}, 3.7 \mathrm{mmol})$ and TBHP $(5.1 \mathrm{~mL}, 56.4 \mathrm{mmol})$. After stirring for $20 \mathrm{~min}$ at -20 ${ }^{\circ} \mathrm{C}$ the allylic alcohol $(3.2 \mathrm{~mL}, 9.4 \mathrm{mmol})$ was added, which was dissolved in dry $\mathrm{CH}_{2} \mathrm{Cl}_{2}(20 \mathrm{~mL})$, then stirred for $12 \mathrm{~h}$ at $-20^{\circ} \mathrm{C}$. The completion of reaction was detected by TLC, then quenched with a $20 \% \mathrm{NaOH}$ solution ( 35 $\mathrm{mL}$ ). The reaction mixture was stirred for a further $5 \mathrm{~h}$ and the reaction mixture was extracted with $\mathrm{CH}_{2} \mathrm{Cl}_{2}$ $(2 \times 20 \mathrm{~mL})$. The combined organic layers were washed with brine and dried over $\mathrm{Na}_{2} \mathrm{SO}_{4}$. Evaporation of the solvent under reduced pressure gave a crude product that was purified by column chromatography using silica gel (60-120 mesh) by eluting with a EtOAc-hexane (2:8) mixture to afford epoxy alcohol 6 (3.2 g, 95\%) as a colorless liquid. Optical rotation $[\alpha]_{D}^{25}-48.6$ (c = 1.5, $\mathrm{CHCl}_{3}$ ). IR (neat) 3589, 2925, 2855, 1697, 1464, 1109,772 $\mathrm{cm}^{-1} ;{ }^{1} \mathrm{H}$ NMR (400 MHz, $\left.\mathrm{CDCl}_{3}\right): \delta 7.72-7.64(\mathrm{~m}, 4 \mathrm{H}), 7.47-7.35(\mathrm{~m}, 6 \mathrm{H}), 3.75-3.60(\mathrm{~m}, 2 \mathrm{H}), 3.46-3.37(\mathrm{~m}$, $1 \mathrm{H}), 2.90(\mathrm{dd}, 1 \mathrm{H}, J 5.6,2.1 \mathrm{~Hz}), 2.69-2.65(\mathrm{~m}, 1 \mathrm{H}), 1.54-1.48(\mathrm{~m}, 1 \mathrm{H}), 1.22(\mathrm{~d}, 3 \mathrm{H}, J 6.2 \mathrm{~Hz}), 1.05(\mathrm{~s}, 9 \mathrm{H}) ;{ }^{13} \mathrm{C}$ NMR $\left(100 \mathrm{MHz}_{\mathrm{CDCl}}\right.$ ): $\delta=135.7,135.9,133.9,129.9,127.6,127.6,68.7,61.2,58.8,57.1,26.9,20.8,19.2$; HRMS (ESI): $m / z$ [M + Na] ${ }^{+}$calcd. for $\mathrm{C}_{21} \mathrm{H}_{28} \mathrm{O}_{3} \mathrm{NaSi}$ : 379.169; found: 379.171 .

(3R,4S)-4-[(t-Butyldiphenylsilyl)oxy]pent-1-yn-3-ol (7). To a stirred solution of epoxy alcohol 6 (3.0 g, 8.4 $\mathrm{mmol})$ in $\mathrm{CCl}_{4}(50 \mathrm{~mL})$ was added TPP $(2.2 \mathrm{~g}, 8.4 \mathrm{mmol})$ and was refluxed for $5 \mathrm{~h}$. After completion of the reaction as indicated by TLC, the reaction mixture was cooled to $0{ }^{\circ} \mathrm{C}$, then diluted with hexane $(30 \mathrm{~mL})$ and filtered through a celite bed. The filtrate was evaporated under reduced pressure and the crude product was purified by column chromatography using silica gel (60-120 mesh) by eluting with a EtOAc-hexane (1:9) mixture to afford, tert-butyl [(S)-1-((2R,3R)-3-(chloromethyl)oxiran-2-yl)ethoxy]diphenyl silane (3.0 g, 95\%) as a colorless oil.

To a stirred solution of the above epoxychloride $(2.9 \mathrm{~g}, 7.75 \mathrm{mmol})$ in anhydrous THF $(20 \mathrm{~mL})$ was added $n$ BuLi $(9.30 \mathrm{~mL}, 23.3 \mathrm{mmol})$ dropwise at $-20{ }^{\circ} \mathrm{C}$ under a nitrogen atmosphere. The reaction mixture was further stirred for $30 \mathrm{~min}$. After completion of the reaction (monitored by TLC), the reaction was quenched by adding saturated $\mathrm{NH}_{4} \mathrm{Cl}$, was then diluted with EtOAc $(30 \mathrm{~mL})$ and extracted with EtOAc $(2 \times 20 \mathrm{~mL})$. The combined organic layers were washed with brine, dried over $\mathrm{Na}_{2} \mathrm{SO}_{4}$, then evaporated under reduced pressure. The crude product was purified by column chromatography using silica gel (60-120 mesh) by eluting with a EtOAchexane (1:9) mixture to afford, alkyne compound $7(2.2 \mathrm{~g}, 85 \%)$ as colorless oil. Optical rotation $[\alpha]_{\mathrm{D}}{ }^{25} 13.5$ (c $=$ 1, $\mathrm{CHCl}_{3}$ ); IR (neat): 3590, 3050, 2926, 2855, 2230, 1464, 1109, $772 \mathrm{~cm}^{-1} ;{ }^{1} \mathrm{H}$ NMR (400 MHz, CDCl 3$): \delta 7.73-$ $7.67(\mathrm{~m}, 4 \mathrm{H}), 7.48-7.37(\mathrm{~m}, 6 \mathrm{H}), 4.30-4.25(\mathrm{~m}, 1 \mathrm{H}), 4.03-3.95(\mathrm{~m}, 1 \mathrm{H}), 2.48-2.42(\mathrm{~m}, 2 \mathrm{H}), 1.15(\mathrm{~d}, 3 \mathrm{H}, \mathrm{J} 6.3$ $\mathrm{Hz}), 1.09(\mathrm{~s}, 9 \mathrm{H}) ;{ }^{13} \mathrm{C} \mathrm{NMR}\left(100 \mathrm{MHz}, \mathrm{CDCl}_{3}\right): \delta$ 135.8, 135.7, 133.6, 133.4, 129.9, 129.8, 127.8, 127.6, 81.6, 74.2, 71.9, 66.9, 26.9, 19.3, 17.9; $\mathrm{HRMS}(\mathrm{ESI}): \mathrm{m} / \mathrm{z}[\mathrm{M}+\mathrm{Na}]^{+}$calcd. for $\mathrm{C}_{21} \mathrm{H}_{26} \mathrm{O}_{2} \mathrm{NaSi}$ : 361.15943; found: 361.16016.

(5R,6S)-5-Ethynyl-6,9,9-trimethyl-8,8-diphenyl-2,4,7-trioxa-8-siladecane (8). To a stirred solution of alkyne 7 (1.5 g, $4.4 \mathrm{mmol})$ in anhydrous $\mathrm{CH}_{2} \mathrm{Cl}_{2}(15 \mathrm{~mL})$ was added subsequently DIPEA (3.9 mL, $22.2 \mathrm{mmol}$ ) and MOM$\mathrm{Cl}(1.0 \mathrm{~mL}, 13.3 \mathrm{mmol}$ ) at r.t. and was then stirred for $12 \mathrm{~h}$. After completion of the reaction (confirmed by $\mathrm{TLC})$, the reaction was quenched with cooled water $(15 \mathrm{~mL})$ and extracted with EtOAc $(2 \times 20 \mathrm{~mL})$. The combined organic layers were dried over $\mathrm{Na}_{2} \mathrm{SO}_{4}$, evaporated under reduced pressure and the crude product was purified by column chromatography using silica gel (60-120 mesh) by eluting with a EtOAc-hexane (1:9) mixture to afford methoxymethyl ether $8(1.52 \mathrm{~g}, 90 \%)$ as a colorless oil. Optical rotation $[\alpha]_{\mathrm{D}}{ }^{25}-49.0$ (c $=0.5$, $\left.\mathrm{CHCl}_{3}\right)$; IR (neat): 3048, 2926, 2855, 2230, 1696, 1465, 1109, 1039, 772, $703 \mathrm{~cm}^{-1} ;{ }^{1} \mathrm{H} \mathrm{NMR}(400 \mathrm{MHz}, \mathrm{CDCl} 3): \delta$ $7.75-7.67(\mathrm{~m}, 4 \mathrm{H}), 7.45-7.34(\mathrm{~m}, 6 \mathrm{H}), 4.91(\mathrm{~d}, 1 \mathrm{H}, J 6.6 \mathrm{~Hz}), 4.60(\mathrm{~d}, 1 \mathrm{H}, J 6.6 \mathrm{~Hz}), 4.37-4.32(\mathrm{~m}, 1 \mathrm{H}), 4.05-$ $3.97(\mathrm{~m}, 1 \mathrm{H}), 3.35(\mathrm{~s}, 3 \mathrm{H}), 2.37(\mathrm{~s}, 1 \mathrm{H}), 1.16(\mathrm{~d}, 3 \mathrm{H}, J 6.1 \mathrm{~Hz}), 1.07(\mathrm{~s}, 9 \mathrm{H}) ;{ }^{13} \mathrm{C} \mathrm{NMR}\left(100 \mathrm{MHz}, \mathrm{CDCl}_{3}\right): \delta 135.9$, 
135.9, 134.2, 133.7, 129.6, 129.5, 127.5, 94.4, 80.6, 74.5, 71.4, 70.4, 55.6, 26.9, 19.3, 18.6; HRMS (ESI): $m / z$ [M $+\mathrm{Na}]^{+}$calcd. for $\mathrm{C}_{23} \mathrm{H}_{30} \mathrm{O}_{3} \mathrm{NaSi}: 405.18564$; found: 405.18593 .

t-Butyl(4-iodobutoxy)dimethylsilane. To a stirred solution of 4-[(tert-butyldimethylsilyl)oxy]butan-1-ol (1.5 g, $7.35 \mathrm{mmol})$ in a toluene-acetonitrile $(3: 1,25 \mathrm{~mL})$ mixture was added TPP $(1.7 \mathrm{~g}, 6.6 \mathrm{mmol})$, imidazole (0.75 g, $11.0 \mathrm{mmol})$ and iodine $(2.8 \mathrm{~g}, 11.0 \mathrm{mmol})$ and was then stirred for $30 \mathrm{~min}$ at r.t. After completion of the reaction (confirmed by TLC), the reaction was terminated with a Hypo solution at $0{ }^{\circ} \mathrm{C}$ and was stirred for 15 min, then extracted with EtOAc $(2 \times 25 \mathrm{~mL})$. The combined organic layers were washed with brine, dried over $\mathrm{Na}_{2} \mathrm{SO}_{4}$ and concentrated under reduced pressure. The crude product was purified by column chromatography using silica gel (60-120 mesh) by eluting with a EtOAc-hexane (5:95) mixture to afford, tert-butyl (4iodobutoxy)dimethylsilane $(1.84 \mathrm{~g}, 98 \%)$ as a colorless oil. IR (neat): $\mathrm{u} 2928,2855,1738,1365,1226,1033$, 836, $774 \mathrm{~cm}^{-1} ;{ }^{1} \mathrm{H}$ NMR (400 MHz, CDCl $)$ : $\delta 3.63(\mathrm{t}, 2 \mathrm{H}, J 6.2 \mathrm{~Hz}), 3.22(\mathrm{t}, 2 \mathrm{H}, J 7.1 \mathrm{~Hz}), 1.94-1.87(\mathrm{~m}, 2 \mathrm{H}), 1.65$ - $1.58(\mathrm{~m}, 2 \mathrm{H}), 0.89(\mathrm{~s}, 9 \mathrm{H}), 0.05(\mathrm{~s}, 6 \mathrm{H}) .{ }^{13} \mathrm{C} \mathrm{NMR}\left(100 \mathrm{MHz}, \mathrm{CDCl}_{3}\right): \delta 61.9,33.5,30.2,25.9,18.3,7.1,-5.3$; HRMS (ESI): $m / z$ [M + Na] ${ }^{+}$calcd. for $\mathrm{C}_{10} \mathrm{H}_{23} \mathrm{INaOSi}$ : 337.01545; found: 337.19723 .

(5S,6R)-6-(Methoxymethoxy)-2,2,5,14,14,15,15-heptamethyl-3,3-diphenyl-4,13-dioxa-3,14-disilahexadec-7yne (9). To a stirred solution of alkyne 8 (1.5 g, $4.5 \mathrm{mmol})$ in a THF-HMPA $(2: 1,10 \mathrm{~mL})$ mixture was added dropwise $n$-BuLi $(1.8 \mathrm{~mL}, 4.5 \mathrm{mmol})$ at $-78{ }^{\circ} \mathrm{C}$ under a nitrogen atmosphere. While adding $n$-BuLi, the reaction mixture converted to a brown color and was then stirred for $30 \mathrm{~min}$ at the same temperature. Then tertbutyl(4-iodobutoxy)dimethylsilane $(1 \mathrm{~g}, 3.2 \mathrm{mmol})$, which was dissolved in THF $(5 \mathrm{~mL})$, was added. The reaction mixture was stirred for $1 \mathrm{~h}$, and allowed to warm up to room temperature. After completion of the reaction (confirmed by $T L C$ ), the reaction waq quenched with saturated $\mathrm{NH}_{4} \mathrm{Cl}$ and the solvent was removed under reduced pressure. The residue was extracted with EtOAc $(2 \times 20 \mathrm{~mL})$ and the combined organic layers were washed with brine, dried over $\mathrm{Na}_{2} \mathrm{SO}_{4}$ and the solvent was evaporated under reduced pressure. The crude product was purified by column chromatography using silica gel, 60-120 mesh by eluting with a EtOAchexane (5:95) mixture to afford the coupled product $9(1.76 \mathrm{~g}, 70 \%)$ as a color less liquid. Optical rotation $[\alpha]_{\mathrm{D}}{ }^{25}-90.1$ (c = 1.0, $\mathrm{CHCl}_{3}$ ); IR (neat): 3045, 2953, 2926, 2856, 2240, 1540, 1465, 1107, 1039, $703 \mathrm{~cm}^{-1} ;{ }^{1} \mathrm{H} \mathrm{NMR}$ $\left(400 \mathrm{MHz}_{\mathrm{CDCl}}\right): \delta 7.75-7.69(\mathrm{~m}, 4 \mathrm{H}), 7.44-7.33(\mathrm{~m}, 6 \mathrm{H}), 4.92(\mathrm{~d}, 1 \mathrm{H}, J 6.6 \mathrm{~Hz}), 4.59(\mathrm{~d}, 1 \mathrm{H}, J 6.7 \mathrm{~Hz}), 4.29-$ $4.27(\mathrm{~m}, 1 \mathrm{H}), 3.99-3.94(\mathrm{~m}, 1 \mathrm{H}), 3.59(\mathrm{t}, 2 \mathrm{H}, \mathrm{J}$ 12.2, $6.5 \mathrm{~Hz}), 3.35(\mathrm{~s}, 3 \mathrm{H}), 2.18(\mathrm{td}, 2 \mathrm{H}, J 7.0,1.8 \mathrm{~Hz}), 1.61-1.49$ $(\mathrm{m}, 3 \mathrm{H}), 1.13(\mathrm{~d}, 3 \mathrm{H}, \mathrm{J} 6.3 \mathrm{~Hz}), 1.07(\mathrm{~s}, 9 \mathrm{H}), 0.88(\mathrm{~s}, 9 \mathrm{H}), 0.03(\mathrm{~s}, 6 \mathrm{H}) ;{ }^{13} \mathrm{C} \mathrm{NMR}\left(100 \mathrm{MHz}, \mathrm{CDCl}_{3}\right): \delta=135.9$, 135.9, 134.4, 134.0, 129.4, 127.4, 94.1, 86.9, 71.8, 70.8, 62.6, 55.4, 31.9, 29.6, 26.9, 25.9, 25.0, 19.2, 18.7, 18.6, -5.3; HRMS (ESI): $m / z[\mathrm{M}+\mathrm{Na}]^{+}$calcd. for $\mathrm{C}_{33} \mathrm{H}_{52} \mathrm{O}_{4} \mathrm{Si}_{2} \mathrm{Na}: 591.32975$; found: 591.32055 .

(7R,8S)-8-[(t-Butyldiphenylsilyl)oxy]-7-(methoxymethoxy)non-5-yn-1-ol (10). To a stirred solution of compound 9 (1.7 g, $3.0 \mathrm{mmol})$ in anhydrous $\mathrm{MeOH}(15 \mathrm{~mL})$ was added PPTS $(0.82 \mathrm{~g}, 3.3 \mathrm{mmol})$ at r.t. and was stirred for $1 \mathrm{~h}$. After completion of the reaction, the solvent was removed and the residue was quenched with $\mathrm{NH}_{4} \mathrm{Cl}$ solution and extracted with EtOAc $(2 \times 10 \mathrm{~mL})$, then the organic layers were washed with brine, dried over $\mathrm{Na}_{2} \mathrm{SO}_{4}$ and evaporated under reduced pressure. The crude product was purified by column chromatography using silica gel (60-120 mesh) by eluting with EtOAc-hexane (2:8) mixture to afford, alcohol $10(1.22 \mathrm{~g}, 90 \%)$ as a colourless oil. Optical rotation $[\alpha]_{\mathrm{D}}{ }^{25}-81.0$ (c $\left.=0.5, \mathrm{CHCl}_{3}\right)$; IR (neat): 3561, 3054, 2925, 2855, 2220, 1697, 1463, 1108, $741 \mathrm{~cm}^{-1} ;{ }^{1} \mathrm{H}$ NMR (400 MHz, CDCl $): \delta 7.74-7.68(\mathrm{~m}, 4 \mathrm{H}), 7.45-7.33(\mathrm{~m}, 6 \mathrm{H})$, $4.91(\mathrm{~d}, 1 \mathrm{H}, J 6.6 \mathrm{~Hz}), 4.59(\mathrm{~d}, 1 \mathrm{H}, J 6.7 \mathrm{~Hz}), 4.29-4.25(\mathrm{~m}, 1 \mathrm{H}), 4.00-3.93(\mathrm{~m}, 1 \mathrm{H}), 3.63(\mathrm{t}, 2 \mathrm{H}, J 12.6,6.3 \mathrm{~Hz})$, $3.35(\mathrm{~s}, 3 \mathrm{H}), 2.20(\mathrm{td}, 2 \mathrm{H}, J 6.8,1.9 \mathrm{~Hz}), 1.65-1.51(\mathrm{~m}, 4 \mathrm{H}), 1.13(\mathrm{~d}, 3 \mathrm{H}, J 6.3 \mathrm{~Hz}), 1.06(\mathrm{~s}, 9 \mathrm{H}) ;{ }^{13} \mathrm{C} \mathrm{NMR}(100$ $\mathrm{MHz}_{\mathrm{CDCl}}$ ): $\delta=35.9,135.9,134.4,133.9,129.5,127.4,94.1,86.7,77.2,71.7,70.8,62.3,55.5,31.8,26.9$, 24.8, 19.3, 18.8, 18.5; HRMS (ESI): $m / z$ [M+Na] ${ }^{+}$calcd. for $\mathrm{C}_{27} \mathrm{H}_{38} \mathrm{O}_{4} \mathrm{SiNa}$ : 477.24316; found: 477.24332 . 
(7R,8S)-8-[(tert-Butyldiphenylsilyl)oxy]-7-(methoxymethoxy)nonan-1-ol (11). To a stirred solution of alcohol 10 (1.1 g, $2.7 \mathrm{mmol})$ in EtOAc $(10 \mathrm{~mL})$ was added Pd/C (10\%, $10 \mathrm{mg})$ at r.t. and was stirred for $10 \mathrm{~h}$, under a hydrogen atmosphere. After completion of the reaction, it was filtered through celite and the filtrate was evaporated under reduced pressure. The crude product was purified by column chromatography using silica gel by eluting with a EtOAc-hexane (2:8) mixture to afford alcohol $11(0.98 \mathrm{~g}, 93 \%)$ as a colourless oil. Optical rotation $[\alpha]_{\mathrm{D}}{ }^{25}+12.25$ ( $\mathrm{c}=0.5, \mathrm{CHCl}_{3}$ ); IR (neat): 3560, 3053, 2922, 2854, 1459, 1108, $1039 \mathrm{~cm}^{-1} ;{ }^{1} \mathrm{H} \mathrm{NMR}(400$ $\left.\mathrm{MHZ}, \mathrm{CDCl}_{3}\right)$ : $\delta 7.70-7.65(\mathrm{~m}, 4 \mathrm{H}), 7.45-7.39(\mathrm{~m}, 6 \mathrm{H}), 4.83(\mathrm{~d}, 1 \mathrm{H}, J 6.6 \mathrm{~Hz}), 4.65(\mathrm{~d}, 1 \mathrm{H}, J 6.6 \mathrm{~Hz}), 3.82(\mathrm{qd}, 1 \mathrm{H}$, J 6.4, $2.7 \mathrm{~Hz}), 3.62(\mathrm{t}, 2 \mathrm{H}, J$ 13.3, $6.7 \mathrm{~Hz}), 3.55-3.49(\mathrm{~m}, 1 \mathrm{H}), 3.37(\mathrm{~s}, 3 \mathrm{H}), 1.64-1.44(\mathrm{~m}, 4 \mathrm{H}), 1.36-1.15(\mathrm{~m}$, 6H), 1.06 (s, 9H), 1.00 (d, 3H, J 6.23 Hz); ${ }^{13} \mathrm{C} \mathrm{NMR} \mathrm{(100} \mathrm{MHz,} \mathrm{CDCl3):} \delta$ 135.9, 135.9, 134.5, 133.8, 129.6, 129.5, 127.5, 127.4, 96.4 81.3, 71.6, 62.9, 55.7, 32.7, 31.2, 29.4, 26.9, 25.8, 25.6, 19.2, 17.9; HRMS (ESI): $m / z$ [M + $\mathrm{Na}]^{+}$calcd. for $\mathrm{C}_{27} \mathrm{H}_{42} \mathrm{O}_{4} \mathrm{SiNa}$ : 481.27446; found: 481.27490 .

(5R,6S)-5-(6-lodohexyl)-6,9,9-trimethyl-8,8-diphenyl-2,4,7-trioxa-8-siladecane (12). To a stirred solution of compound $11(0.9 \mathrm{~g}, 2.0 \mathrm{mmol})$ in a toluene-acetonotrile $(3: 1,15 \mathrm{~mL})$ mixture were added TPP $(0.46 \mathrm{~g}, 1.76$ $\mathrm{mmol})$, imidazole $(0.2 \mathrm{~g}, 2.7 \mathrm{mmol})$ and iodine $(0.75 \mathrm{~g}, 1.8 \mathrm{mmol})$. The mixture was then stirred for $30 \mathrm{~min}$ at r.t. and changed to a thick brown color. After completion of the reaction (confirmed by TLC), the reaction mixture was quenched by adding a saturated Hypo at $0{ }^{\circ} \mathrm{C}$ and was stirred for 15 min. The mixture was extracted with EtOAc $(2 \times 10 \mathrm{~mL})$ and the combined organic layers were washed with brine, dried over $\mathrm{Na}_{2} \mathrm{SO}_{4}$ and the solvent was evaporated under reduced pressure. The crude compound was purified by column chromatography using silica gel (60-120 mesh) by eluting with a EtOAc-hexane (5:95) mixture to afford, iodide compound $12(1.05 \mathrm{~g}, 95 \%)$ as a color less oil. Optical rotation $[\alpha]_{\mathrm{D}}{ }^{25}+11.80$ (c $\left.=0.5, \mathrm{CHCl}_{3}\right)$; IR (neat): 3054, 2926, 2855, 1320, 1107, 1037, 739, $703 \mathrm{~cm}^{-1}$; ${ }^{1} \mathrm{H}$ NMR (400 MHz, CDCl $)$ : $\delta 7.79-7.66(\mathrm{~m}, 4 \mathrm{H}), 7.45-7.35(\mathrm{~m}$, $6 \mathrm{H}), 4.82(\mathrm{~d}, 1 \mathrm{H}, J 6.5 \mathrm{~Hz}), 4.64(\mathrm{~d}, 1 \mathrm{H}, J 6.7 \mathrm{~Hz}), 3.84-3.79(\mathrm{qd}, 1 \mathrm{H}, J 6.4,2.7 \mathrm{~Hz}), 3.53-3.49(\mathrm{~m}, 1 \mathrm{H}), 3.37(\mathrm{~s}$, $3 \mathrm{H}), 3.17(\mathrm{t}, 2 \mathrm{H}, J 14.2,7.1 \mathrm{~Hz}), 1.82-1.75(\mathrm{~m}, 2 \mathrm{H}), 1.44-1.50(\mathrm{~m}, 1 \mathrm{H}) 1.38-1.8(\mathrm{~m}, 7 \mathrm{H}), 1.06(\mathrm{~s}, 9 \mathrm{H}), 1.01(\mathrm{~d}$, $3 \mathrm{H}$, J $6.25 \mathrm{~Hz}) ;{ }^{13} \mathrm{C} \mathrm{NMR}\left(100 \mathrm{MHz}, \mathrm{CDCl}_{3}\right): \delta 135.9,135.9,134.5,133.8,129.6,129.5,127.5, \quad 127.4, \quad 96.4$, 81.2, 71.6, 55.7, 33.4, 31.1, 30.4, 28.5, 26.9, 25.6, 19.2, 17.9, 7.2; HRMS (ESI): $\mathrm{m} / z$ [M+Na] ${ }^{+} \mathrm{calcd}$. for $\mathrm{C}_{27} \mathrm{H}_{41} \mathrm{O}_{3} \mathrm{INaSi}: 591.17619$; found: 591.17642 .

(5R,6S)-5-\{8-[(4R,5S)-5-((Benzyloxy)methyl)-2,2-dimethyl-1,3-dioxolan-4-yl]oct-7-yn-1-yl\}-6,9,9-trimethyl8,8-diphenyl-2,4,7-trioxa-8-siladecane (13). To a stirred solution of alkyne 3 (0.56 g, $2.3 \mathrm{mmol})$ in a THFHMPA $(2: 1,5 \mathrm{~mL})$ mixture was added dropwise $n$-BuLi $(0.78 \mathrm{~mL}, 2.0 \mathrm{mmol})$ at $-78{ }^{\circ} \mathrm{C}$ under a nitrogen atmosphere. While adding $n$-BuLi dropwise, the reaction mass converted to a brown color and was then stirred for a further $30 \mathrm{~min}$ at the same temperature. Then, a solution of iodo compound $12(0.9 \mathrm{~g}, 1.5 \mathrm{mmol})$, which was dissolved in THF $(5 \mathrm{~mL})$, was added. The reaction mixture was stirred for a further $1 \mathrm{~h}$, and gradually warmed to room temperature. After completion of the reaction, the reaction was terminated with saturated $\mathrm{NH}_{4} \mathrm{Cl}$ and extracted with EtOAc $(2 \times 20 \mathrm{~mL})$. The combined organic layers were washed with brine, dried over $\mathrm{Na}_{2} \mathrm{SO}_{4}$ and concentrated under reduced pressure. The residue was purified by column chromatography using silica gel (60-120 mesh) by eluting with a EtOAc-hexane (0.5:9.5) mixture to afford 13 (0.76 g, 73\%) as a color less liquid. Optical rotation $[\alpha]_{\mathrm{D}}^{25}+31.37\left(\mathrm{c}=1, \mathrm{CHCl}_{3}\right.$ ); IR (neat): $\mathrm{u} 2926,2855,2250,1428,1107,1038 \mathrm{~cm}^{-1}$; ${ }^{1} \mathrm{H}$ NMR $\left(400 \mathrm{MHz}_{\mathrm{CDCl}}\right): \delta 7.71-7.65(\mathrm{~m}, 4 \mathrm{H}), 7.45-7.30(\mathrm{~m}, 10 \mathrm{H}), 4.85-4.81(\mathrm{~m}, 2 \mathrm{H}), 4.67-4.60(\mathrm{~m}, 2 \mathrm{H})$, $4.57-4.51(\mathrm{~m}, 1 \mathrm{H}), 4.33-4.27(\mathrm{~m}, 1 \mathrm{H}), 3.82(\mathrm{qd}, 1 \mathrm{H}, \mathrm{J} 6.2,2.6 \mathrm{~Hz}), 3.74-3.68(\mathrm{~m}, 2 \mathrm{H}), 3.54-3.48(\mathrm{~m}, 1 \mathrm{H})$, $3.36(\mathrm{~s}, 3 \mathrm{H}), 2.20-2.14(\mathrm{td}, 2 \mathrm{H}, J 7.1,1.9 \mathrm{~Hz}), 1.53(\mathrm{~s}, 3 \mathrm{H}), 1.50-1.40(\mathrm{~m}, 4 \mathrm{H}), 1.38-1.12(\mathrm{~m}, 10 \mathrm{H}), 1.06(\mathrm{~s}, 9 \mathrm{H})$, $1.01(\mathrm{~d}, 3 \mathrm{H}, \mathrm{J} 6.4 \mathrm{~Hz}) ;{ }^{13} \mathrm{C} \mathrm{NMR}\left(100 \mathrm{MHz}, \mathrm{CDCl}_{3}\right): \delta$ 137.9, 135.9, 135.9, 134.5, 133.8, 129.6, 129.5, 128.3, $127.8,127.7,127.5,127.4,109.9,96.4,88.4,81.3,76.6,75.4,73.6,71.6,70.2,67.9,55.7,31.2,29.1,28.8$, 
28.4, 27.7, 26.9, 25.9, 25.7, 19.2, 18.7, 17.9; HRMS (ESI): $m / z$ [M+Na] $]^{+}$calcd. for $\mathrm{C}_{42} \mathrm{H}_{58} \mathrm{O}_{6} \mathrm{SiNa}$ 70: 709.38949; found: 709.38949 .

\{(4S,5R)-5-[(9R,10S)-10-((tert-Butyldiphenylsilyl)oxy)-9-(methoxymethoxy)undecyl]-2,2-dimethyl-1,3-di oxolan-4-yl\}methanol (14). To a stirred solution of compound 13 (0.65 g, $0.95 \mathrm{mmol})$ in EtOAc (5 mL) was added $\mathrm{Pd} / \mathrm{C}(10 \%, 10 \mathrm{mg})$ at r.t. and was stirred under a hydrogen atmosphere for $10 \mathrm{~h}$. After completion of the reaction (confirmed by TLC), it was filtered through a celite bed and the filtrate was concentrated under vacuum pressure. The residue was purified by column chromatography using silica gel (60-120 mesh) by eluting with a EtOAc-hexane (3:7) mixture to afford, alcohol $14(0.51 \mathrm{~g}, 90 \%)$ as a color less oil. Optical rotation $[\alpha]_{\mathrm{D}}{ }^{25}+8.0$ ( $\left.\mathrm{c}=0.5, \mathrm{CHCl}_{3}\right)$; IR (neat): 3542, 3026, 2924, 2855, 1533, 1460, 1107, $1039 \mathrm{~cm}^{-1} ;{ }^{1} \mathrm{H} \mathrm{NMR}(400 \mathrm{MHz}$, $\left.\mathrm{CDCl}_{3}\right): \delta 7.71-7.65(\mathrm{~m}, 4 \mathrm{H}), 7.44-7.34(\mathrm{~m}, 6 \mathrm{H}), 4.83(\mathrm{~d}, 1 \mathrm{H}, J 6.6 \mathrm{~Hz}), 4.65(\mathrm{~d}, 1 \mathrm{H}, J 6.6 \mathrm{~Hz}), 4.18-4.11(\mathrm{~m}$, $1 \mathrm{H}), 3.92-3.85(\mathrm{~m}, 1 \mathrm{H}), 3.85-3.77(\mathrm{~m}, 1 \mathrm{H}), 3.76-3.70(\mathrm{~m}, 1 \mathrm{H}), 3.60-3.57(\mathrm{~m}, 1 \mathrm{H}), 3.54-3.50(\mathrm{~m}, 1 \mathrm{H}), 3.37(\mathrm{~s}$, $3 \mathrm{H}), 1.51-1.36(\mathrm{~m}, 8 \mathrm{H}), 1.34-1.13(\mathrm{~m}, 14 \mathrm{H}), 1.06(\mathrm{~s}, 9 \mathrm{H}), 1.00(\mathrm{~d}, 3 \mathrm{H}, J 6.4 \mathrm{~Hz}) ;{ }^{13} \mathrm{C} \mathrm{NMR}\left(100 \mathrm{MHz}_{,} \mathrm{CDCl}_{3}\right): \delta$ 135.9, 135.9, 134.6, 133.8, 129.5, 129.5, 127.5, 127.4, 108.5, 96.4, 81.5, 81.3, 77.9, 76.9, 71.7, 62.0, 61.8, 55.6, 33.1, 31.3, 29.6, 29.4, 28.8, 28.2, 27.3, 26.9, 26.6, 25.9, 25.8, 25.5, 19.1, 17.8; HRMS (ESI): $\mathrm{m} / z$ [M+Na] ${ }^{+} \mathrm{calcd}$. for $\mathrm{C}_{35} \mathrm{H}_{56} \mathrm{O}_{6} \mathrm{NaSi}: 623.37384$; found: 623.37484 .

\section{Ethyl-(E)-3-\{(4S,5R)-5-[(9R,10S)-10-((tert-butyldiphenylsilyl)oxy)-9-(methoxymethoxy)undecyl]-2,2-di}

methyl-1,3-dioxolan-4-yl\}acrylate (15). To a stirred solution of alcohol 14 (0.45 g, $0.75 \mathrm{mmol})$ in anhydrous $\mathrm{CH}_{2} \mathrm{Cl}_{2}(10 \mathrm{~mL})$ was added DMP $(0.41 \mathrm{~g}, 0.97 \mathrm{mmol})$ and $\mathrm{NaHCO}_{3}(110 \mathrm{mg}, 0.44 \mathrm{mmol})$ at $0{ }^{\circ} \mathrm{C}$ for $15 \mathrm{~min}$, and was then slowly warmed to room temperature for $1 \mathrm{~h}$. The completion of the reaction was monitored by TLC, then cooled to $0{ }^{\circ} \mathrm{C}$ and the reaction was quenched with crushed ice and was extracted with $\mathrm{CH}_{2} \mathrm{Cl}_{2}(2 \times 10 \mathrm{~mL})$. The combined organic layers were washed with brine, dried over $\mathrm{Na}_{2} \mathrm{SO}_{4}$, the solvent was evaporated under reduced pressure and the obtained aldehyde was used for the following Wittig reaction without purification.

To a stirred solution of the above aldehyde in toluene $(10 \mathrm{~mL})$ was added $\mathrm{Ph}_{3} \mathrm{P}=\mathrm{CHCO}_{2} \mathrm{Et}(0.29 \mathrm{~g}, 0.83 \mathrm{mmol})$ and the resulting mixture was refluxed for $2 \mathrm{~h}$. After completion of the reaction (confirmed by TLC), the reaction was terminated with water and extracted with EtOAc $(2 \times 15 \mathrm{~mL})$. The combined organic layer was dried over $\mathrm{Na}_{2} \mathrm{SO}_{4}$, the solvent was evaporated under reduced pressure and the residue product was purified by column chromatography using silica gel (60-120 mesh) by eluting with a EtOAc-hexane (1:9) mixture to afford, ester compound $15(0.19 \mathrm{~g}, 75 \%)$ as a colorless liquid. Optical rotation $[\alpha]_{\mathrm{D}}{ }^{25}+5.25(\mathrm{c}=0.5, \mathrm{CHCl} 3) ; \mathrm{IR}$ (neat): 3045, 2924, 2854, 1525, 1462, 1217, $772 \mathrm{~cm}^{-1} ;{ }^{1} \mathrm{H}$ NMR (400 MHz, CDCl $)$ : $\delta 7.70-7.65$ (m, $\left.4 \mathrm{H}\right), 7.44-$ $7.34(\mathrm{~m}, 6 \mathrm{H}), 6.86(\mathrm{dd}, 1 \mathrm{H}, J 15.7,5.7 \mathrm{~Hz}), 6.11(\mathrm{dd}, 1 \mathrm{H}, J 15.5,1.3 \mathrm{~Hz}), 4.83(\mathrm{~d}, 1 \mathrm{H}, J 6.6 \mathrm{~Hz}), 4.65(\mathrm{~d}, 1 \mathrm{H}, J 6.6$ $\mathrm{Hz}), 4.21(q, 2 \mathrm{H}), 4.17-4.12(\mathrm{~m}, 1 \mathrm{H}), 3.85-3.79(q d, 1 \mathrm{H}, J 6.2,2.7 \mathrm{~Hz}), 3.76-3.70(\mathrm{~m}, 1 \mathrm{H}), 3.54-3.49(\mathrm{~m}, 1 \mathrm{H})$, $3.36(\mathrm{~s}, 3 \mathrm{H}), 1.42(\mathrm{~d}, 6 \mathrm{H}, J 10.8 \mathrm{~Hz}), 1.36(\mathrm{~m}, 19 \mathrm{H}), 1.05(\mathrm{~s}, 9 \mathrm{H}), 1.00(\mathrm{~d}, 3 \mathrm{H}, J 6.4 \mathrm{~Hz}) ;{ }^{13} \mathrm{C} \mathrm{NMR}(100 \mathrm{MHz}$, $\left.\mathrm{CDCl}_{3}\right): \delta=165.9,143.8,135.9,134.6,133.5,128.6,129.5,127.5,127.4,122.9,108.8,96.4,81.3,78.4,71.7$, $60.5,55.7,31.9,31.3,30.5,25.7,29.7,29.4,28.0,26.9,26.3,25.8,25.3,19.2,17.9,14.2 ; \mathrm{HRMS}$ (ESI): $\mathrm{m} / \mathrm{z}$ $[\mathrm{M}+\mathrm{Na}]^{+}$calcd. for $\mathrm{C}_{39} \mathrm{H}_{60} \mathrm{O}_{7} \mathrm{SiNa}$ : 691.40005; found 691.40123.

Ethyl(E)-3-\{(4S,5R)-5-[(9R,10S)-10-hydroxy-9-(methoxymethoxy)undecyl]-2,2-dimethyl-1,3-dioxolan-4-yl\} acrylate (16). To a stirred solution of ester compound 15 (0.3 g, $0.44 \mathrm{mmol})$ in anhydrous THF (5 mL) in a plastic vial was added the $\mathrm{HF} \bullet \mathrm{Py}$ complex $(70 \%, 0.1 \mathrm{~mL})$ at $0{ }^{\circ} \mathrm{C}$. The reaction mixture was slowly warmed to room temperature and was stirred for $24 \mathrm{~h}$. The completion of the reaction was confirmed by TLC, then carefully poured in a saturated $\mathrm{NaHCO}_{3}$ solution $(5 \mathrm{~mL})$ and was stirred for 30 min and extracted with EtOAc $(2 \times 10 \mathrm{~mL})$. The combined organic layers were further washed with a saturated $\mathrm{CuSO}_{4}(5 \mathrm{~mL})$ solution, water $(5$ $\mathrm{mL}$ ), brine $(5 \mathrm{~mL})$ and then the organic layer was dried over $\mathrm{Na}_{2} \mathrm{SO}_{4}$ and concentrated under pressure. The residue product was purified by column chromatography using silica gel, (60-120 mesh) by eluting with a 
EtOAc-heaxane (1:9) mixture to afford the secondary alcohol $16(0.14 \mathrm{~g}, 75 \%)$ as a colorless liquid. Optical rotation $[\alpha]_{D}{ }^{25}+5.30\left(c=1, \mathrm{CHCl}_{3}\right) .{ }^{\mathrm{Lit}}[\alpha]_{\mathrm{D}}{ }^{20}+7.18\left(\mathrm{c}=1, \mathrm{CHCl}_{3}\right)^{4}$; IR (neat): 3556, 2924, 2854, 1725, 1432, 1254, 1034, $772 \mathrm{~cm}^{-1} ;{ }^{1} \mathrm{H}$ NMR (400 MHz, $\mathrm{CDCl}_{3}$ ): $\delta 6.84$ (dd, 1H, J 15.7, $6.2 \mathrm{~Hz}$ ), 6.06 (dd, 1H, J 15.7, $1.5 \mathrm{~Hz}$ ), $4.74(\mathrm{~d}$, $1 \mathrm{H}$, J $6.9 \mathrm{~Hz}), 4.67-4.61(\mathrm{~m}, 2 \mathrm{H}), 4.24-4.18(\mathrm{~m}, 4 \mathrm{H}), 3.79-3.7(\mathrm{~m}, 1 \mathrm{H}), 3.52-3.47(\mathrm{~m}, 1 \mathrm{H}), 3.43(\mathrm{~s}, 3 \mathrm{H}), 3.06$ (brs, $1 \mathrm{H}), 1.51(\mathrm{~s}, 3 \mathrm{H}), 1.38(\mathrm{~s}, 3 \mathrm{H}), 1.32-1.23(\mathrm{~m}, 18 \mathrm{H}) 1.14(\mathrm{~d}, 3 \mathrm{H}, J 6.5 \mathrm{~Hz}) ;{ }^{13} \mathrm{C} \mathrm{NMR}(100 \mathrm{MHz}, \mathrm{CDCl} 3): \delta$ 166.0, 143.8, 122.9, 108.8, 97.6, 85.2, 78.3, 77.2, 68.9, 60.5, 55.8, 30.9, 30.5, 29.7, 29.6, 29.4, 28.0, 26.3, 26.0, 25.5, 17.1, 14.2. HRMS (ESI): $m / z$ [M+Na] ${ }^{+}$calcd. for $\mathrm{C}_{23} \mathrm{H}_{42} \mathrm{O}$ ( SiNa: 453.28227; found: 453.28375 .

\section{Acknowledgements}

Authors AT and KB are thankful to UGC-New Delhi and CSIR-New Delhi respectively for providing fellowships. We also thank the Minister of Science and Technology for providing financial support under DST-SERBEEQ/2018/001311. We are grateful to the Director CSIR-IICT for providing facilities.

IICT Communication No: IICT/Pubs./2018/185.

\section{Supplementary Material}

Copies of ${ }^{1} \mathrm{H}$ and ${ }^{13} \mathrm{C}$ NMR of compounds 2-16 are available in the Supplementary Material file associated with this manuscript.

\section{References}

1. Kito, K.; Ookura, R.; Yoshida, S.; Namikoshi, M.; Ooi, T.; Kusumi, T. Org. Lett. 2008, 10, 225. https://doi.org/10.1021/ol702598q

2. Hande, S. M., Uenishi, J. Tetrahedron Lett. 2009, 50, 189. https://doi.org/10.1016/j.tetlet.2008.10.115

3. Bao, J.; Xu, X. Y.; Zhang, X. Y.; Qi, S. H. Nat. Prod. Commun. 2013, 8, 1127. https://doi.org/10.1021/acs.orglett.5b00138

4. Bignanshu, K. J.; Reddy, G. S.; Mohapatra, D. K. Org. Biomol. Chem. 2017, 15, 1863. https://doi.org/10.1039/C6OB02435A

5. Nagalatha, G.; Ganesh, N. S.; Narsaiah, A. V. SynOpen 2018, 2, 251. https://doi.org/10.24820/ark.5550190.p010.795

6. Ghogare, R. S.; Wadavrao, S. B.; Narsaiah, A. V. Helv. Chim. Acta. 2016, 99, 247. https://doi.org/10.1002/hlca.201500110

7. Ganesh, N. S.; Nagalatha, G.; Narsaiah, A. V. Arkivoc 2018, (vii), 495. https://doi.org/10.24820/ark.5550190.p010.795

8. Karunakar, B.; Anil, T.; Narsaiah, A. V. SynOpen 2019, 3, 26.

9. Bernet, B.; Vasella, A. Helv. Chim. Acta. 1979, 62, 1990. https://doi.org/10.1002/hlca.19790620629

10. Gallos, J.K.; Goga, E.G.; Koumbis, A. E. J. Chem. Soc., Perkin Trans. 1 1994, 611. 
https://doi.org/10.1039/p19940000611

11. Leo, A. P.; Simon, B. J. Org. Chem. 1995, 60, 7849.

12. Ewen, D. D.; Ahmed, M. Z.; Andrew, S. J. Org. Chem. 2013, 78, 7223.

13. Stephan, G. D.; Foster, E. M.; Lee, J. A.; Roberts, P. M.; Thomson, J. E. Tetrahedron Asym. 2014, $25,534$.

14. W.; Mei, Y.; Kang, Y.; Hua, Z.; Jin, Z. Org. Lett. 2004, 6, 3217.

https://doi.org/10.1021/ol0400342

15. Wadavrao, S. B.; Ghogare, R. S.; Narsaiah, A. V. Tetrahedron Lett. 2013, 54, 5674.

https://doi.org/10.1016/j.tetlet.2013.07.164

16. Srihari, P.; Mahankali. B.; Prasad, K. R. Tetrahedron Lett. 2012, 53, 56.

https://doi.org/10.1016/j.tetlet.2011.10.137

17. Yadav. J. S.; Reddy. G. M.; Rao. T. S.; Reddy, B. V. S. Synthesis 2012, 44, 783.

https://doi.org/10.1055/s-0031-1289703

18. Katsuki, T.; Sharpless, K. B. J. Am. Chem. Soc. 1980, 102, 5976.

https://doi.org/10.1021/ja00538a077

19. Narsaiah, A. V.; Ghogare, R. S. Synthesis 2011, 20, 3271.

https://doi.org/10.1055/s-0030-1260214

20. Wadavrao, S. B.; Ghogare, R. S.; Narsaiah, A. V. Tetrahedron Lett. 2012, 53, 3955.

21. Yadav, J. S.; Deshpande, P. K.; Sharma, G. V. M. Tetrahedron 1990, 46, 7033.

https://doi.org/10.1016/S0040-4020(01)87888-1

22. Sabitha, G.; Rao, A. S.; Yadav, J.S. Tetrahedron Asym. 2011, 22, 8, 866.

https://doi.org/10.1016/j.tetasy.2011.04.024

23. Mohapatra, D. K.; Umamaheshwer, G.; Rao, R. N.; Rao, T. S.; Kumar, R. S.; Yadav, J. S. Org. Lett. 2015, 17, 979.

24. Chen, B. S.; Yang, L. H.; Ye, J. L.; Huang, T.; Ruan, Y. P.; Fu, J.; Huang, P. Q. Eur. J. Med. Chem. 2011, 46, 5480.

https://doi.org/10.1176/pn.46.21.psychnews 4621201

25. Semmelhack, M. F.; Gallagher, J. Tetrahedron Lett. 1993, 31, 4121.

26. Das, T.; Nanda, S. Tetrahedron Lett. 2012, 53, 256.

https://doi.org/10.1016/j.tetlet.2011.11.059

27. Crimmins, M. T.; She, J. J. Am. Chem. Soc. 2004, 126, 12790.

https://doi.org/10.1021/ja0455852

28. Koch, G.; Loiseleur, O.; Altmann, K. H. Synlett 2004, 693.

https://doi.org/10.1055/s-2004-817771

29. Maier, M. E.; Rink, C.; Sasse, F.; Zubriene, A.; Matulis, D. Chem. Eur. J. 2010, 16, 14469. https://doi.org/10.1002/chem.201001752

30. Reddy, Y.; Sabitha, G. Chem. Select. 2016, 1, 2156. https://doi.org/10.1002/slct.201600512

31. Njardarson, J. T.; Gaul, C.; Shan, D.; Huang, X. Y.; Danishefsky, S. J. J. Am. Chem. Soc. 2004, 126, 1038. https://doi.org/10.1021/ja039714a

32. Sebastien, R.; Cossy, J. Tetrahedron 2007, 63, 5913. 